\title{
Orexin-1 Receptor Antagonism Does Not Reduce the Rewarding Potency of Cocaine in Swiss-Webster Mice
}

\author{
Thorfinn T. Riday, Eric W. Fish, J. Elliott Robinson, Thomas M. Jarrett, Megan M. \\ McGuigan, and C.J. Malanga \\ Laboratory of Developmental Neuropharmacology; Department of Neurology; University of North \\ Carolina at Chapel Hill
}

\begin{abstract}
The orexin family of hypothalamic neuropeptides has been implicated in reinforcement mechanisms relevant to both food and drug reward. Previous behavioral studies with antagonists at the orexin A-selective receptor, $\mathrm{OX}_{1}$, have demonstrated its involvement in behavioral sensitization, conditioned place-preference, and self-administration of drugs of abuse. Adult male Swiss-Webster mice were implanted with stimulating electrodes to the lateral hypothalamus and trained to perform intracranial self-stimulation (ICSS). The effects of the $\mathrm{OX}_{1}$-selective antagonist SB 334867 on brain stimulation-reward (BSR) and cocaine potentiation of BSR were measured. SB $334867(10-30 \mathrm{mg} / \mathrm{kg}$, i.p.) alone had no effect on ICSS performance or BSR threshold. Cocaine $(1.0-30 \mathrm{mg} / \mathrm{kg}$ i.p.) dose-dependently potentiated BSR, measured as lowering of BSR threshold. This effect was not blocked by $30 \mathrm{mg} / \mathrm{kg}$ SB 334867 at any cocaine dose tested. In agreement with previous reports, SB 334867 resulted in a reduction of body weight 24 hours after acute administration. Based on these data, it is concluded that orexins acting at $\mathrm{OX}_{1}$ do not contribute to BSR; and are not involved in the reward-potentiating actions of cocaine on BSR. The data are discussed in the context of prior findings of SB 334867 effects on drug-seeking and drugconsuming behaviors.
\end{abstract}

\section{Keywords}

Brain Stimulation Reward; Hypocretin; Psychostimulant; Intracranial Self-Stimulation

\section{INTRODUCTION}

Since the orexin family of hypothalamic neuropeptides were first described over a decade ago (de Lecea et al. 1998; Sakurai et al. 1998) they have been implicated in arousal (Adamantidis et al. 2007; de Lecea et al. 1998; Nishino 2007; Nishino et al. 2000), appetitive behaviors (Clegg et al. 2002; Nair et al. 2008; Sakurai et al. 1998; Zheng et al. 2007); and reward processing (Aston-Jones et al. 2009; Borgland et al. 2010; Boutrel et al. 2005; DiLeone et al. 2003; Harris et al. 2005; Sharf et al. 2010b). Both orexin A (OxA) and orexin $\mathrm{B}(\mathrm{OxB})$ are synthesized from one gene product, prepro-orexin, by hypothalamic neurons; and act through two distinct G-protein coupled receptor systems, $\mathrm{OX}_{1}$ and $\mathrm{OX}_{2}$.

(C) 2011 Elsevier B.V. All rights reserved.

Corresponding Author: C.J. Malanga, M.D., Ph.D., Department of Neurology, University of North Carolina at Chapel Hill, 170 Manning Dr., CB 7025, Chapel Hill, NC 27599-7025, Tel: (919) 966-1683, Fax: (919) 843-4576, malangacj@ neurology.unc.edu.

Publisher's Disclaimer: This is a PDF file of an unedited manuscript that has been accepted for publication. As a service to our customers we are providing this early version of the manuscript. The manuscript will undergo copyediting, typesetting, and review of the resulting proof before it is published in its final citable form. Please note that during the production process errors may be discovered which could affect the content, and all legal disclaimers that apply to the journal pertain. 
$\mathrm{OX}_{1}$ has a significantly higher affinity for $\mathrm{OxA}$, while $\mathrm{OX}_{2}$ has similar affinity for $\mathrm{OxA}$ and OxB (Sakurai et al. 1998).

Orexin-containing neurons projecting from the lateral hypothalamus ( $\mathrm{LH})$ to the mesencephalic ventral tegmental area (VTA; (Peyron et al. 1998) have been shown to be involved in drug preference (Harris et al. 2005) and reinstatement of drug selfadministration following extinction (Boutrel et al. 2005; Smith et al. 2009). These findings can be partially explained by the observation that orexins increase firing rate and/or promote burst firing of dopaminergic VTA neurons (Korotkova et al. 2003) thereby facilitating dopamine release in brain regions receiving VTA projections (Narita et al. 2006; Vittoz and Berridge 2006; Vittoz et al. 2008). Both OxA and OxB enhance glutamatergic signaling in the VTA, although OxA appears to preferentially affect synaptic transmission associated with positive reinforcers (Borgland et al. 2009; Borgland et al. 2008).

Intracranial self-stimulation (ICSS) is an operant behavioral method in which animals are trained to deliver reinforcing electrical stimulation (brain stimulation reward, or BSR) to discrete elements of brain reward circuitry. Specifically, mice self-stimulate the medial forebrain bundle (MFB) in the LH, which includes ascending dopaminergic fibers from the VTA to the limbic forebrain, particularly the nucleus accumbens (NAc) and prefrontal cortex (Wise 2002). The MFB is also adjacent to orexin neurons of the LH, raising the possibility that orexin release itself plays a role in BSR (DiLeone et al. 2003; Lawrence 2010). The ability of drugs to potentiate or attenuate the rewarding value of BSR can be determined by measuring ICSS responses after acute or chronic drug treatment. Acute administration of drugs of abuse, regardless of their pharmacological class, potentiates the rewarding value of BSR (Kornetsky and Bain 1992; Kornetsky and Duvauchelle 1994).

In these experiments, we investigated the effects of the $\mathrm{OX}_{1}$ antagonist SB 334867 (SB) on BSR and cocaine reward using ICSS. This orexin antagonist has been shown to reduce home cage feeding (Clegg et al. 2002; Zheng et al. 2007) and decrease operant self-administration of high-fat containing food (Borgland et al. 2009; Nair et al. 2008). SB does not decrease fixed-ratio cocaine self-administration (Espana et al. 2010; Smith et al. 2009), but does decrease breakpoint on progressive-ratio schedules of cocaine self-administration (Borgland et al. 2009; Espana et al. 2010), suggesting that $\mathrm{OX}_{1}$ antagonism may reduce the rewarding value of cocaine (Richardson and Roberts 1996). SB also blocks stress- and cue-induced but not drug-induced reinstatement of cocaine self-administration after extinction (Boutrel et al. 2005; Smith et al. 2009). To test the hypothesis that $\mathrm{OX}_{1}$ antagonism decreases the rewardpotentiating effect of cocaine on BSR, we measured changes in BSR threshold $\left(\theta_{0}\right)$ and maximum operant response rates following SB administration alone and before cocaine.

\section{RESULTS}

\subsection{Effects of SB 334867 on Body Weight}

Consistent with its previously-reported anorexic effects, mice lost weight after acute intermittent administration of SB (Figure 1A). Body weights were decreased 24 hours after each dose of SB, and a significant main effect of SB treatment was seen $\left(F_{(3,46)}=3.41, P<\right.$ 0.05 ), although the dose-dependence of this effect was non-significant (SB $30 \mathrm{mg} / \mathrm{kg}$ vs. 10 $\mathrm{mg} / \mathrm{kg}, P=0.069$ ). Daily average body weights aligned to the first dose of SB are shown in Figure 1B. On day 14 all mice $(n=13)$ received SB $(10,20$ or $30 \mathrm{mg} / \mathrm{kg}) ; 10 / 13$ mice received $\mathrm{SB}$ on day $16 ; 7 / 13$ on day 18 ; and $6 / 12$ on day 20 ; after which no more than $5 / 12$ mice received SB on any given experimental day. By day 17 more than half of the mice (7/13) had lost an average of $3.2 \pm 1.1 \mathrm{~g}(P=$ N.S. $)$ from the day prior to the first SB dose. By day 20, average body weight returned to pre-SB levels and remained constant through 
day 31, after which no further SB experiments were performed and average daily weights subsequently increased.

\subsection{Effects of SB 334867 on Brain Stimulation Reward}

As we have previously shown, cocaine produces orderly leftward shifts of the ICSS ratefrequency curve in outbred Swiss-Webster mice (Figure 2). Acute administration of SB alone $\left(10,20\right.$ or $30 \mathrm{mg} / \mathrm{kg}$ i.p.) had no significant independent effect on $\theta_{0}\left(F_{(3,50)}\langle 1.0, P\rangle\right.$ $0.5)$ or maximum operant response rate $\left(F_{(3,50)}<2.6, P>0.1\right.$; Figure 3$)$. Acute administration of cocaine (Figure 4, white circles) significantly lowered $\theta_{0}$ (Min. 1-15: $F_{(4,119)}=2.6, P<0.05 ;$ Min. 16-30: $\left.F_{(4,119)}=2.9, P<0.05\right)$ with a potency and time course similar to our previous reports in this outbred strain of mice (Gilliss et al. 2002; Malanga et al. 2008). When administered 30 minutes prior to acute cocaine (Figure 4, black circles), SB $(30 \mathrm{mg} / \mathrm{kg}$ ) increased the reward-potentiating effect of $3.0 \mathrm{mg} / \mathrm{kg}$ cocaine during the first 30 minutes of recording (Min. 1-15: $P<0.001$; Min. 16-30: $P<0.01$ vs. cocaine alone), but no parallel horizontal shift of the dose-response curve to cocaine on BSR was observed; that is, no differences in cocaine effects on $\theta_{0}$ were seen between pretreatment with vehicle or 30 $\mathrm{mg} / \mathrm{kg} \mathrm{SB}$ at any time point after administration of $1.0,10$ or $30 \mathrm{mg} / \mathrm{kg}$ cocaine.

During ICSS training and testing the current amplitude is kept constant; however, the frequency range for each animal is adjusted prior to drug testing such that only the highest 4-6 frequencies sustain responding. Therefore, comparison of $\theta_{0}$ expressed as electrical charge delivery (in Coulombs, $\mathrm{C}$ ) is a more robust comparison of baseline reward function across days (see 4.2 Intracranial Self-Stimulation, below) or between treatment and control groups. Every-other day testing with SB did not progressively change baseline $\theta_{0}$ over the course of the full experiment (Figure 5).

\section{DISCUSSION}

Orexins directly increase the excitability of dopaminergic VTA neurons in vitro (Borgland et al. 2008; Borgland et al. 2006; Korotkova et al. 2003), and systemic administration of the $\mathrm{OX}_{1}$ antagonist $\mathrm{SB}$ reduces spontaneous and evoked activity of dopaminergic neurons in vivo (Moorman and Aston-Jones 2010; Rasmussen et al. 2007). However, we observed no effect of systemic administration of SB alone at doses up to $30 \mathrm{mg} / \mathrm{kg}$ on BSR threshold $\left(\theta_{0}\right)$ or maximum operant response rate. Three prior reports investigated the role of orexins in BSR in rats using rate- or discrete trial-based measures of ICSS. BSR threshold was significantly elevated by intraventricular (Boutrel et al. 2005) or intra-VTA infusion of OxA (Hata et al. 2011), an effect which may be due to orexin-mediated release of corticotropinreleasing factor (CRF; Hata et al. 2011; Macey et al. 2000). However, systemic doses up to $6 \mathrm{mg} / \mathrm{kg}$ of SB alone did not affect BSR threshold but did block the reward-potentiating effect of nicotine on BSR (Hollander et al. 2008). We conclude from our data that while electrical self-stimulation of the LH elicits BSR in mice, direct stimulation of orexinergic neurons in the LH and subsequent release of orexins acting at the $\mathrm{OX}_{1}$ receptor does not contribute to BSR, consistent with recent findings that ICSS alone does not activate significant numbers of lateral hypothalamic orexinergic neurons (Hata et al. 2011). Based on the lack of effect of SB on maximum operant response rates we conclude that ICSS performance is unaffected by $\mathrm{OX}_{1}$ antagonism. However, because SB was only given to mice that had already learned to respond for BSR, we cannot determine from these data whether $\mathrm{OX}_{1}$ antagonism would interfere with the instrumental learning processes necessary to acquire operant responding for BSR.

Given its low aqueous solubility, it is reasonable to question the absorption and distribution of SB after intraperitoneal injection. We solubilized SB in DMSO and cyclodextrin similar to other laboratories performing whole-animal pharmacology experiments with similar SB 
doses (Borgland et al. 2009; Borgland et al. 2006; Boutrel et al. 2005; Espana et al. 2010; Harris et al. 2005; LeSage et al. 2010). Consistent with prior reports (Haynes et al. 2002; Haynes et al. 2000; Rodgers et al. 2001), we observed reductions in body weight 24 hours after acute SB administration. This suggests that under our solubilization conditions and at these doses, SB is systemically absorbed, crosses the blood-brain barrier, and affects feeding behavior. While it is possible that this overnight reduction in body weight, which may reflect an acute anorexic effect of SB, is due to peripheral effects such as reduction in gastrointestinal motility, interruption of normal enteric peptide hormone activity, or changes in glucocorticoid balance, all of which are affected by OxA (Baccari 2010; Heinonen et al. 2008; Kagerer and Johren 2010), this was not directly addressed in these experiments.

Our data show that SB has no significant effect on the dose-response relationship of cocaine potentiation of BSR in Swiss-Webster mice, unlike its ability to block potentiation of BSR by nicotine in rats (Hollander et al. 2008). Potentiation of BSR by cocaine was slightly increased at one dose $(3.0 \mathrm{mg} / \mathrm{kg})$ in the presence of SB; however, the dose-response curve of cocaine on BSR was otherwise unaffected by SB, with no changes observed at 1.0, 10 or $30 \mathrm{mg} / \mathrm{kg}$ cocaine at any time point after injection. Thus, SB pretreatment results in no horizontal shift of the dose-response curve of cocaine at half-log dose increments.

Additional doses at quarter-log increments (i.e., $5.6 \mathrm{mg} / \mathrm{kg}$ ) were not given, as the doseresponse relationship to cocaine is shallow in this strain compared to C57BL/6J or DBA/2J mice, in which the cocaine dose-response curve is steeper (Fish et al. 2010). These findings are in direct contrast to the inhibitory effects of SB on cocaine potentiation of BSR we hypothesized based on the finding that $\mathrm{SB}$ reduces of breakpoints in progressive-ratio (PR) cocaine self-administration suggesting that $\mathrm{OX}_{1}$ signaling contributes to cocaine reward (Borgland et al. 2009; Espana et al. 2010).

The effects of SB on reward-relevant behaviors are complex, varying with both the drug and the conditions under which they are tested (see summary in Table 1; reviewed in Sharf et al. 2010b). SB attenuates the development of conditioned place-preference to amphetamine (Hutcheson et al. 2011) and morphine (Harris et al. 2005; Narita et al. 2006; Sharf et al. 2010a), but neither to cocaine (Sharf et al. 2010a) nor alcohol (Shoblock et al. 2011; Voorhees and Cunningham 2011). SB also blocks the development of behavioral sensitization to amphetamine (Quarta et al. 2010) and cocaine (Borgland et al. 2006) but not to morphine (Sharf et al. 2010a). While SB reduces fixed-ratio (FR) self-administration of nicotine as well as BSR potentiation by nicotine (Hollander et al. 2008; LeSage et al. 2010), FR cocaine self-administration and, based on our data, BSR potentiation by cocaine are unaffected by SB (Espana et al. 2010; Smith et al. 2009). However, as for nicotine (Hollander et al. 2008), breakpoints for PR cocaine self-administration are reduced by SB (Borgland et al. 2009; Espana et al. 2010). SB also prevents stress- and cue-induced but not drug-induced reinstatement of both cocaine (Boutrel et al. 2005; Smith et al. 2009) and alcohol self-administration (Lawrence et al. 2006; Richards et al. 2008) after extinction.

There are two caveats regarding the interpretation of our data in light of these previous reports. First, both rate-dependent and rate-independent measures of ICSS (Hollander et al. 2008) demonstrate no effect of SB on BSR itself, confirming that orexin release from lateral hypothalamic neurons is unlikely to contribute to BSR (Hata et al. 2011). However, unlike in BSR, the role of $\mathrm{OX}_{1}$ signaling in drug reward appears to vary with the pharmacological mechanism of the drug of abuse tested (Sharf et al. 2010a; Sharf et al. 2010b), the potency of the drug in question as a primary reinforcer, or both. Second, unlike cocaine reward measured with self-administration, in which cocaine itself is the primary reinforcer, in ICSS BSR is the primary reinforcer, the potency of which is increased by cocaine. Using this method we are able determine if and how much cocaine potentiates the value of the primary reinforcer, BSR, but not the absolute reinforcing efficacy of cocaine in and of itself; that is, 
not the ability of cocaine to act as a primary reinforcer. With these caveats, our data support the conclusion that antagonism of the $\mathrm{OX}_{1}$ receptor does not attenuate the rewarding potency of cocaine measured with ICSS.

The idea that orexin signaling is involved in effort related to acquisition of high-value rewards as opposed to less potent reinforcers has experimental support (Borgland et al. 2009). In this view, orexin signaling acts as a behavioral high-pass filter, such that the motivation to acquire rewards with low salience, or for which the ratio of effort required to the value of the reinforcer is high, is preferentially affected by $\mathrm{OX}_{1}$ antagonism. This formulation does not explain why SB would block place conditioning to amphetamine and opioids but not cocaine, which may be related to a role for $\mathrm{OX}_{1}$ signaling in learning mechanisms. However, it does explain why SB attenuates self-administration of alcohol and nicotine - both relatively low-potency primary reinforcers for rodent self-administration - on an FR schedule, but only blocks cocaine self-administration on a PR schedule, where the behavioral cost to attain a high-value reinforcer is increased. Investigation into the effects of $\mathrm{OX}_{1}$ antagonism on amphetamine and opioid self-administration would be informative in this regard. This formulation predicts that an $\mathrm{OX}_{1}$ antagonist would reduce breakpoints on PR self-administration of amphetamine or heroin - both high-potency primary reinforcers but may also reduce self-administration of morphine, an opioid with lower reinforcing potency than heroin, on an FR schedule. This model is also consistent with the lack of SB effects on BSR itself, in that BSR is undoubtedly a primary reinforcer of extremely high potency. It may also explain the effects of SB on cue- and stress-induced reinstatement of drug self-administration, in which negative (i.e., stress) or positive (i.e., environmental context) stimuli of relatively lesser salience compared to drug reward fail to induce drug seeking after $\mathrm{OX}_{1}$ antagonism, but reinstating stimuli with higher potency and a lower behavioral cost to the animal (i.e. non-contingent drug administration) are unaffected.

An alternative explanation for our data is based on the anatomical distribution and sites of action of $\mathrm{OX}_{1}$. Mapping of mRNA for orexin receptors has shown that $\mathrm{OX}_{2}$ but not $\mathrm{OX}_{1}$ is expressed in the NAc, while both $\mathrm{OX}_{1}$ and $\mathrm{OX}_{2}$ are expressed in the VTA (Marcus et al. 2001; Trivedi et al. 1998). One proposed model of orexin actions on drug-seeking behaviors suggests a different role of orexin signaling for drugs of abuse with a primary site of action in the VTA (e.g., opioids) compared to those with a primary site of action in the NAc (e.g., cocaine; see Figure 7 in Aston-Jones et al. 2009). Dopamine release in the NAc is clearly a final common pathway in ICSS, although both direct stimulation of ascending dopaminergic fibers from the VTA (Cheer et al. 2007; Kuhr et al. 1987) and indirect activation of dopaminergic VTA neurons through stimulation of descending glutamatergic fibers (Herberg and Rose 1990; You et al. 2001) and activation of cholinergic relays from pontine tegmental nuclei (Chen et al. 2006; Yeomans et al. 1985) have been implicated. Because the reward-potentiating activity of cocaine on BSR may be more closely related to its activity at dopaminergic terminals than on VTA neuronal firing rate, it may be the case that antagonism of VTA OX 1 receptors is insufficient to overcome the direct effect of cocaine on forebrain terminal release. In contrast, the reward-potentiating effect of nicotine is likely related to its activation of VTA firing through both direct stimulation of nAChRs on dopaminergic VTA neurons (Yeomans and Baptista 1997) and indirect activation of cholinergic afferents to VTA (Chen et al. 2006), which may explain why BSR potentiation by nicotine, but not cocaine, is blocked by SB. Experiments using transgenic mice in which orexin receptor expression is selectively inactivated in specific neuronal populations (Mochizuki et al. 2011) or the use of optogenetics to stimulate or inhibit endogenous orexin release in a site-specific manner (Rolls et al. 2011) will be helpful in dissecting orexin mechanisms in drug reward, and will clarify the brain circuits within which orexin signaling is important for the behavioral effects of abused drugs with different cellular targets and mechanisms of action (Yamanaka and Tsunematsu 2010). 
Manipulation of orexin signaling remains a target of significant therapeutic interest for both drug- and food-related addictive disorders. Given the apparent complexity of the actions of orexins in reward processing, significant further study of the role of orexins in drug- and context-specific neural activity, including their role in basic learning mechanisms, will be necessary before orexin antagonists are positioned to be safely considered for clinical trials. However, the observations that $\mathrm{OX}_{1}$ antagonism does not reduce brain reward but does block stress- and cue-induced reinstatement of drug-seeking suggests that this class of compounds may be useful additions to stress-reduction and other behavioral therapies in the treatment of substance abuse disorders.

\section{EXPERIMENTAL PROCEDURE}

\subsection{Animal Care and Handling}

All experimental animal procedures were carried out according to the NIH Guide to the Care and Use of Laboratory Animals and were approved by the Institutional Animal Care and Use Committee at the University of North Carolina at Chapel Hill.

\subsection{Intracranial Self-Stimulation (ICSS)}

Fifteen male white Swiss-Webster mice (Taconic Labs, Hudson NY) P50-P60 or weighing $>25 \mathrm{~g}$ were anesthetized (ketamine/xylazine 120/18 mg/kg i.p.; Sigma, St. Louis MO) and stereotaxically implanted with an insulated monopolar stainless steel electrode $(0.28 \mathrm{~mm}$ diameter; Plastics One, Roanoke VA) to the right MFB at the level of the LH (Figure 6) using coordinates from Paxinos and Franklin (1996): bregma $-2.0 \mathrm{~mm}(\mathrm{a} / \mathrm{p})$, sagital -0.8 $\mathrm{mm}(\mathrm{m} / \mathrm{l})$ and depth $-4.5 \mathrm{~mm}(\mathrm{~d} / \mathrm{v})$. A stainless steel screw (electrical ground) and the electrode assembly were secured to the skull with dental cement. After recovery, mice were individually housed in polycarbonate cages $(28 \times 17 \times 14 \mathrm{~cm})$ lined with cob bedding and covered with stainless steel wire lids. Mice were allowed free access to dry food (Purina rodent chow) and tap water ad libitum. The vivarium was kept at $21 \pm 1{ }^{\circ} \mathrm{C}$ and $30-40 \%$ humidity on a 12-hour light/dark cycle (lights off at 8:00 AM). All ICSS experiments were performed during the dark cycle, and began approximately 4 hours into the active phase.

One week after implantation mice were trained on a continuous (FR-1) schedule of reinforcement for brain stimulation reward (BSR) in a $16 \times 14 \times 13 \mathrm{~cm}$ operant chamber with a wheel manipulandum and a house light (MedAssociates, St. Albans VT). Each quarter-turn of the wheel earned a $500 \mathrm{msec}$ train of unipolar cathodal square-wave current at a frequency of $158 \mathrm{~Hz}$ (pulse width $=100 \mu \mathrm{sec}$ ) and activated the house light for 500 msec. Subsequent responses during the $500 \mathrm{msec}$ did not earn additional stimulation. Optimal stimulus intensity to sustain reliable responding ( $\geq 40$ responses $/ \mathrm{min}$ ) was determined for animals individually during training, and varied between -90 and $-220 \mu \mathrm{A}$. Current intensity was kept constant for each animal for all experiments. One mouse failed to reliably respond for BSR during training and was not used for subsequent experiments.

Mice were then presented a series of training stimulus frequencies in descending order from $158 \mathrm{~Hz}$ to $19 \mathrm{~Hz}$ in discrete $0.05 \log _{10}$ increments (i.e., $\log _{10}[112 \mathrm{~Hz}]=2.05 ; \log _{10}[100 \mathrm{~Hz}]$ $=2.00$, etc.). At each frequency, five non-contingent priming stimuli were followed by 50 sec ad libitum access to BSR delivered on an FR-1 schedule during which responses were measured. A 5 sec time-out period followed each trial frequency during which responses earned no additional stimulation. Mice were trained to complete four series of 15 trial frequencies (i.e., one hour daily). After training, the range of frequencies was adjusted for each mouse such that only the highest 4-6 frequencies would sustain responding. For each series of 15 stimulus frequencies, the rate of operant responding for BSR was plotted (i.e., the rate-frequency curve, see Figure 3$)$. BSR threshold $\left(\theta_{0}\right)$ was defined as the X-intercept of 
the least-squares regression line through frequencies that sustained responding at 20,30,40, 50 and $60 \%$ of the maximal response rate in each series, and was calculated automatically by custom-designed software at the end of each experiment. This method of reward threshold determination is less sensitive to changes in response rate than other calculations, e.g., the frequency sustaining $1 / 2$ - maximal response, or EF50 (Miliaressis et al. 1986). Saline injections began in each animal when its mean BSR threshold varied $< \pm 10 \%$ over three consecutive days.

On each testing day, three series of 15 frequencies were acquired before injection with vehicle or drug. The first series served as a warm-up and was discarded; $\theta_{0}$ and maximum rate from the second and third rate-frequency curves were averaged and used as baselines. The $\mathrm{OX}_{1}$ antagonist SB 334867 (SB; Tocris Bioscience, Ellisville MO) was solubilized in DMSO (20\% v/v) and hydroxypropyl $\beta$-cyclodextrin (25\% w/v) in sterile normal $(0.9 \%)$ saline and was prepared fresh daily. SB and cocaine $\mathrm{HCl}$ (in sterile normal saline; Sigma) were administered by intraperitoneal injection. In initial experiments, $\theta_{0}$ and maximum response rates were measured for four 15 -minute series immediately following SB $(10,20$ or $30 \mathrm{mg} / \mathrm{kg}$ ) or vehicle injection. In subsequent experiments, mice were injected with SB (30 $\mathrm{mg} / \mathrm{kg}$ ) or vehicle and two 15 -minute series were acquired, followed by injection with cocaine $(1.0,3.0,10$ or $30 \mathrm{mg} / \mathrm{kg}$, calculated as the free base) and acquisition of four additional 15-minute series. Pretreatment with SB for 30 minutes prior to various behavioral measurements is within the range commonly reported by several other laboratories (Borgland et al. 2009; Harris et al. 2005; Lawrence et al. 2006; Richards et al. 2008; Sharf et al. 2010a). Mice were tested with drug every other day and with saline or vehicle injections on alternate days. For each drug tested, doses were presented in random order. All data were analyzed as percent changes from baseline $\theta_{0}$ or maximum response rate on that day. One mouse died between the SB and SB + cocaine experiments and one mouse lost its electrode headstage before the completion of full SB + cocaine dose-response determinations, for a final $n$ of 12 mice.

\subsection{Histology}

At the end of all experiments, brains were fixed with paraformaldehyde $(4 \% \mathrm{w} / \mathrm{v}$ in $0.1 \mathrm{M}$ phosphate buffered saline) and serial coronal frozen sections $(50 \mu \mathrm{m})$ were collected through the ICSS electrode tract, mounted onto Superfrost Plus (Fisher Scientific, Pittsburgh PA) slides; stained with cresyl violet for Nissl; and viewed under low-power (4X) light microscopy for confirmation of electrode tip placements (Figure 6).

\subsection{Statistical Analysis}

One-way ANOVA was used to determine effects of SB 334867 administration on body weight. Two-way ANOVA (dose $\times$ time after injection) with post-hoc (Bonferroni) comparisons for significant main effects was used to determine effects of drugs on BSR threshold $\left(\theta_{0}\right)$ and maximum operant response rate.

\section{HIGHLIGHTS}

- Orexin signaling is involved in the rewarding effects of drugs of abuse.

Effects of the $\mathrm{OX}_{1}$ receptor antagonist SB 334867 were investigated in outbred mice.

- SB 334867 does not affect electrical brain stimulation reward (BSR) in mice.

SB 334867 does not block the ability of cocaine to potentiate BSR in mice. 


\section{Abbreviations}

$\begin{array}{ll}\text { BSR } & \text { Brain stimulation-reward } \\ \text { ICSS } & \text { Intracranial self-stimulation } \\ \text { LH } & \text { Lateral hypothalamus } \\ \text { MFB } & \text { Medial forebrain bundle } \\ \text { NAc } & \text { Nucleus accumbens } \\ \text { SB 334867 } & \text { N-(2-Methyl-6-benzoxazolyl)-N'-1,5-naphthyridin-4-yl urea } \\ \text { VTA } & \text { Ventral tegmental area }\end{array}$

\section{Acknowledgments}

This work was supported by the National Institute on Drug Abuse (DA K08 015429 to CJM). The authors thank Dr. Stephanie Borgland for helpful discussions in the preparation of this manuscript.

\section{REFERENCES}

Adamantidis AR, Zhang F, Aravanis AM, Deisseroth K, de Lecea L. Neural substrates of awakening probed with optogenetic control of hypocretin neurons. Nature. 2007; 450:420-424. [PubMed: 17943086]

Aston-Jones G, Smith RJ, Moorman DE, Richardson KA. Role of lateral hypothalamic orexin neurons in reward processing and addiction. Neuropharmacology. 2009; 56 Suppl 1:112-121. [PubMed: 18655797]

Baccari BC. Orexins and gastrointestinal functions. Curr Protein Pept Sci. 2010; 11:148-155. [PubMed: 20353399]

Borgland SL, Chang SJ, Bowers MS, Thompson JL, Vittoz N, Floresco SB, Chou J, Chen BT, Bonci A. Orexin a/hypocretin-1 selectively promotes motivation for positive reinforcers. J Neurosci. 2009; 29:11215-11225. [PubMed: 19741128]

Borgland SL, Storm E, Bonci A. Orexin b/hypocretin 2 increases glutamatergic transmission to ventral tegmental area neurons. Eur J Neurosci. 2008; 28:1545-1556. [PubMed: 18793323]

Borgland SL, Taha SA, Sarti F, Fields HL, Bonci A. Orexin a in the vta is critical for the induction of synaptic plasticity and behavioral sensitization to cocaine. Neuron. 2006; 49:589-601. [PubMed: 16476667]

Borgland SL, Ungless MA, Bonci A. Convergent actions of orexin/hypocretin and crf on dopamine neurons: Emerging players in addiction. Brain Res. 2010; 1314:139-144. [PubMed: 19891960]

Boutrel B, Kenny PJ, Specio SE, Martin-Fardon R, Markou A, Koob GF, de Lecea L. Role for hypocretin in mediating stress-induced reinstatement of cocaine-seeking behavior. Proc Natl Acad Sci U S A. 2005; 102:19168-19173. [PubMed: 16357203]

Cheer JF, Aragona BJ, Heien ML, Seipel AT, Carelli RM, Wightman RM. Coordinated accumbal dopamine release and neural activity drive goal-directed behavior. Neuron. 2007; 54:237-244. [PubMed: 17442245]

Chen J, Nakamura M, Kawamura T, Takahashi T, Nakahara D. Roles of pedunculopontine tegmental cholinergic receptors in brain stimulation reward in the rat. Psychopharmacology (Berl). 2006; 184:514-522. [PubMed: 16385418]

Clegg DJ, Air EL, Woods SC, Seeley RJ. Eating elicited by orexin-a, but not melanin-concentrating hormone, is opioid mediated. Endocrinology. 2002; 143:2995-3000. [PubMed: 12130565]

de Lecea L, Kilduff TS, Peyron C, Gao X, Foye PE, Danielson PE, Fukuhara C, Battenberg EL, Gautvik VT, Bartlett FS 2nd, Frankel WN, van den Pol AN, Bloom FE, Gautvik KM, Sutcliffe JG. The hypocretins: Hypothalamus-specific peptides with neuroexcitatory activity. Proc Natl Acad Sci U S A. 1998; 95:322-327. [PubMed: 9419374] 
DiLeone RJ, Georgescu D, Nestler EJ. Lateral hypothalamic neuropeptides in reward and drug addiction. Life Sci. 2003; 73:759-768. [PubMed: 12801597]

Espana RA, Oleson EB, Locke JL, Brookshire BR, Roberts DC, Jones SR. The hypocretin-orexin system regulates cocaine self-administration via actions on the mesolimbic dopamine system. Eur J Neurosci. 2010; 31:336-348. [PubMed: 20039943]

Fish EW, Riday TT, McGuigan MM, Faccidomo S, Hodge CW, Malanga CJ. Alcohol, cocaine, and brain stimulation-reward in c57bl6/j and dba2/j mice. Alcohol Clin Exp Res. 2010; 34:81-89. [PubMed: 19860803]

Gilliss B, Malanga CJ, Pieper JO, Carlezon WA Jr. Cocaine and skf-82958 potentiate brain stimulation reward in swiss-webster mice. Psychopharmacology (Berl). 2002; 163:238-248. [PubMed: 12202971]

Harris GC, Wimmer M, Aston-Jones G. A role for lateral hypothalamic orexin neurons in reward seeking. Nature. 2005; 437:556-559. [PubMed: 16100511]

Hata T, Chen J, Ebihara K, Date Y, Ishida Y, Nakahara D. Intra-ventral tegmental area or intracerebroventricular orexin-a increases the intra-cranial self-stimulation threshold via activation of the corticotropin-releasing factor system in rats. Eur J Neurosci. 2011; 34:816-826. [PubMed: 21848921]

Haynes AC, Chapman H, Taylor C, Moore GB, Cawthorne MA, Tadayyon M, Clapham JC, Arch JR. Anorectic, thermogenic and anti-obesity activity of a selective orexin-1 receptor antagonist in ob/ ob mice. Regul Pept. 2002; 104:153-159. [PubMed: 11830290]

Haynes AC, Jackson B, Chapman H, Tadayyon M, Johns A, Porter RA, Arch JR. A selective orexin-1 receptor antagonist reduces food consumption in male and female rats. Regul Pept. 2000; 96:4551. [PubMed: 11102651]

Heinonen MV, Purhonen AK, Makela KA, Herzig KH. Functions of orexins in peripheral tissues. Acta Physiol (Oxf). 2008; 192:471-485. [PubMed: 18294339]

Herberg LJ, Rose IC. Excitatory amino acid pathways in brain-stimulation reward. Behav Brain Res. 1990; 39:230-239. [PubMed: 1978779]

Hollander JA, Lu Q, Cameron MD, Kamenecka TM, Kenny PJ. Insular hypocretin transmission regulates nicotine reward. Proc Natl Acad Sci U S A. 2008; 105:19480-19485. [PubMed: 19033203]

Hutcheson DM, Quarta D, Halbout B, Rigal A, Valerio E, Heidbreder C. Orexin-1 receptor antagonist sb-334867 reduces the acquisition and expression of cocaineconditioned reinforcement and the expression of amphetamine-conditioned reward. Behav Pharmacol. 2011; 22:173-181. [PubMed: 21285875]

Kagerer SM, Johren O. Interactions of orexins/hypocretins with adrenocortical functions. Acta Physiol (Oxf). 2010; 198:361-371. [PubMed: 19719797]

Kornetsky C, Bain G. Brain-stimulation reward: A model for the study of the rewarding effects of abused drugs. NIDA Res Monogr. 1992; 124:73-93. [PubMed: 1470216]

Kornetsky C, Duvauchelle C. Dopamine, a common substrate for the rewarding effects of brain stimulation reward, cocaine, and morphine. NIDA Res Monogr. 1994; 145:19-39. [PubMed: 8742806]

Korotkova TM, Sergeeva OA, Eriksson KS, Haas HL, Brown RE. Excitation of ventral tegmental area dopaminergic and nondopaminergic neurons by orexins/hypocretins. J Neurosci. 2003; 23:7-11. [PubMed: 12514194]

Kuhr WG, Wightman RM, Rebec GV. Dopaminergic neurons: Simultaneous measurements of dopamine release and single-unit activity during stimulation of the medial forebrain bundle. Brain Res. 1987; 418:122-128. [PubMed: 3499205]

Lawrence AJ. Regulation of alcohol-seeking by orexin (hypocretin) neurons. Brain Res. 2010; 1314:124-129. [PubMed: 19646424]

Lawrence AJ, Cowen MS, Yang HJ, Chen F, Oldfield B. The orexin system regulates alcohol-seeking in rats. Br J Pharmacol. 2006; 148:752-759. [PubMed: 16751790]

LeSage MG, Perry JL, Kotz CM, Shelley D, Corrigall WA. Nicotine self-administration in the rat: Effects of hypocretin antagonists and changes in hypocretin mRNA. Psychopharmacology (Berl). 2010; 209:203-212. [PubMed: 20177882] 
Macey DJ, Koob GF, Markou A. CRF and urocortin decreased brain stimulation reward in the rat: Reversal by a CRF receptor antagonist. Brain Res. 2000; 866:82-91. [PubMed: 10825483]

Malanga CJ, Riday TT, Carlezon WA Jr, Kosofsky BE. Prenatal exposure to cocaine increases the rewarding potency of cocaine and selective dopaminergic agonists in adult mice. Biol Psychiatry. 2008; 63:214-221. [PubMed: 17568568]

Marcus JN, Aschkenasi CJ, Lee CE, Chemelli RM, Saper CB, Yanagisawa M, Elmquist JK. Differential expression of orexin receptors 1 and 2 in the rat brain. J Comp Neurol. 2001; 435:625. [PubMed: 11370008]

Miliaressis E, Rompre PP, Laviolette P, Philippe L, Coulombe D. The curve-shift paradigm in selfstimulation. Physiol Behav. 1986; 37:85-91. [PubMed: 3016774]

Mochizuki T, Arrigoni E, Marcus JN, Clark EL, Yamamoto M, Honer M, Borroni E, Lowell BB, Elmquist JK, Scammell TE. Orexin receptor 2 expression in the posterior hypothalamus rescues sleepiness in narcoleptic mice. Proc Natl Acad Sci U S A. 2011; 108:4471-4476. [PubMed: 21368172]

Moorman DE, Aston-Jones G. Orexin/hypocretin modulates response of ventral tegmental dopamine neurons to prefrontal activation: Diurnal influences. J Neurosci. 2010; 30:15585-15599. [PubMed: 21084614]

Nair SG, Golden SA, Shaham Y. Differential effects of the hypocretin 1 receptor antagonist sb 334867 on high-fat food self-administration and reinstatement of food seeking in rats. Br J Pharmacol. 2008; 154:406-416. [PubMed: 18223663]

Narita M, Nagumo Y, Hashimoto S, Khotib J, Miyatake M, Sakurai T, Yanagisawa M, Nakamachi T, Shioda S, Suzuki T. Direct involvement of orexinergic systems in the activation of the mesolimbic dopamine pathway and related behaviors induced by morphine. J Neurosci. 2006; 26:398-405. [PubMed: 16407535]

Nishino S. The hypothalamic peptidergic system, hypocretin/orexin and vigilance control. Neuropeptides. 2007; 41:117-133. [PubMed: 17376528]

Nishino S, Ripley B, Overeem S, Lammers GJ, Mignot E. Hypocretin (orexin) deficiency in human narcolepsy. Lancet. 2000; 355:39-40. [PubMed: 10615891]

Paxinos, GT.; Franklin, KB. The mouse brain in stereotaxic coordinates. 2 edn.. San Diego: Academic Press; 1996.

Peyron C, Tighe DK, van den Pol AN, de Lecea L, Heller HC, Sutcliffe JG, Kilduff TS. Neurons containing hypocretin (orexin) project to multiple neuronal systems. J Neurosci. 1998; 18:999610015. [PubMed: 9822755]

Quarta D, Valerio E, Hutcheson DM, Hedou G, Heidbreder C. The orexin-1 receptor antagonist SB-334867 reduces amphetamine-evoked dopamine outflow in the shell of the nucleus accumbens and decreases the expression of amphetamine sensitization. Neurochem Int. 2010; 56:11-15. [PubMed: 19737591]

Rasmussen K, Hsu MA, Yang Y. The orexin-1 receptor antagonist sb-334867 blocks the effects of antipsychotics on the activity of a 9 and a10 dopamine neurons: Implications for antipsychotic therapy. Neuropsychopharmacology. 2007; 32:786-792. [PubMed: 17063151]

Richards JK, Simms JA, Steensland P, Taha SA, Borgland SL, Bonci A, Bartlett SE. Inhibition of orexin-1/hypocretin-1 receptors inhibits yohimbine-induced reinstatement of ethanol and sucrose seeking in long-evans rats. Psychopharmacology (Berl). 2008; 199:109-117. [PubMed: 18470506]

Richardson NR, Roberts DC. Progressive ratio schedules in drug self-administration studies in rats: A method to evaluate reinforcing efficacy. J Neurosci Methods. 1996; 66:1-11. [PubMed: 8794935]

Rodgers RJ, Halford JC, Nunes de Souza RL, Canto de Souza AL, Piper DC, Arch JR, Upton N, Porter RA, Johns A, Blundell JE. SB-334867, a selective orexin-1 receptor antagonist, enhances behavioural satiety and blocks the hyperphagic effect of orexin-A in rats. Eur J Neurosci. 2001; 13:1444-1452. [PubMed: 11298806]

Rolls A, Colas D, Adamantidis A, Carter M, Lanre-Amos T, Heller HC, de Lecea L. Optogenetic disruption of sleep continuity impairs memory consolidation. Proc Natl Acad Sci U S A. 2011; 108:13305-13310. [PubMed: 21788501]

Sakurai T, Amemiya A, Ishii M, Matsuzaki I, Chemelli RM, Tanaka H, Williams SC, Richarson JA, Kozlowski GP, Wilson S, Arch JR, Buckingham RE, Haynes AC, Carr SA, Annan RS, McNulty 
DE, Liu WS, Terrett JA, Elshourbagy NA, Bergsma DJ, Yanagisawa M. Orexins and orexin receptors: A family of hypothalamic neuropeptides and $\mathrm{g}$ protein-coupled receptors that regulate feeding behavior. Cell. 1998; 921 page following 696.

Sharf R, Guarnieri DJ, Taylor JR, DiLeone RJ. Orexin mediates morphine place preference, but not morphine-induced hyperactivity or sensitization. Brain Res. 2010a; 1317:24-32. [PubMed: 20034477]

Sharf R, Sarhan M, Dileone RJ. Role of orexin/hypocretin in dependence and addiction. Brain Res. 2010b; 1314:130-138. [PubMed: 19699189]

Shoblock JR, Welty N, Aluisio L, Fraser I, Motley ST, Morton K, Palmer J, Bonaventure P, Carruthers NI, Lovenberg TW, Boggs J, Galici R. Selective blockade of the orexin-2 receptor attenuates ethanol self-administration, place preference, and reinstatement. Psychopharmacology (Berl). 2011; 215:191-203. [PubMed: 21181123]

Smith RJ, See RE, Aston-Jones G. Orexin/hypocretin signaling at the orexin 1 receptor regulates cueelicited cocaine-seeking. Eur J Neurosci. 2009; 30:493-503. [PubMed: 19656173]

Trivedi P, Yu H, MacNeil DJ, Van der Ploeg LH, Guan XM. Distribution of orexin receptor mRNA in the rat brain. FEBS Lett. 1998; 438:71-75. [PubMed: 9821961]

Vittoz NM, Berridge CW. Hypocretin/orexin selectively increases dopamine efflux within the prefrontal cortex: Involvement of the ventral tegmental area. Neuropsychopharmacology. 2006; 31:384-395. [PubMed: 15988471]

Vittoz NM, Schmeichel B, Berridge CW. Hypocretin /orexin preferentially activates caudomedial ventral tegmental area dopamine neurons. Eur J Neurosci. 2008; 28:1629-1640. [PubMed: 18973582]

Voorhees CM, Cunningham CL. Involvement of the orexin/hypocretin system in ethanol conditioned place preference. Psychopharmacology (Berl). 2011; 214:805-818. [PubMed: 21107540]

Wise RA. Brain reward circuitry: Insights from unsensed incentives. Neuron. 2002; 36:229-240. [PubMed: 12383779]

Yamanaka A, Tsunematsu T. New approaches for the study of orexin function. J Neuroendocrinol. 2010; 22:818-824. [PubMed: 20456607]

Yeomans J, Baptista M. Both nicotinic and muscarinic receptors in ventral tegmental area contribute to brain-stimulation reward. Pharmacol Biochem Behav. 1997; 57:915-921. [PubMed: 9259024]

Yeomans JS, Kofman O, McFarlane V. Cholinergic involvement in lateral hypothalamic rewarding brain stimulation. Brain Res. 1985; 329:19-26. [PubMed: 3872153]

You ZB, Chen YQ, Wise RA. Dopamine and glutamate release in the nucleus accumbens and ventral tegmental area of rat following lateral hypothalamic self-stimulation. Neuroscience. 2001; 107:629-639. [PubMed: 11720786]

Zheng H, Patterson LM, Berthoud HR. Orexin signaling in the ventral tegmental area is required for high-fat appetite induced by opioid stimulation of the nucleus accumbens. J Neurosci. 2007; 27:11075-11082. [PubMed: 17928449] 


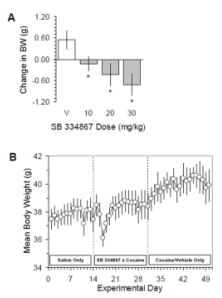

\section{Figure 1.}

A. Interval change in body weight (mean \pm SEM) measured 24 hours after each dose of the orexin-A receptor antagonist SB 334867. $* P<0.05$ vs. vehicle (V). B. Average daily weight of all mice $(n=12-13) \pm$ SEM before, during and after administration of SB 334867. Prior to day 14 (left dashed line) mice received only saline; and after day 31 (right dashed line) received only cocaine and/or saline or vehicle $(20 \% \mathrm{v} / \mathrm{v} \mathrm{DMSO}+25 \% \mathrm{w} / \mathrm{v}$ cyclodextran). A decrease in average mouse weight was evident by the third day after the start of SB 334867 exposure $(36.1 \pm 0.6 \mathrm{~g})$ compared to the day prior to the first SB 334867 administration $(38.1 \pm 0.9 \mathrm{~g})$. See Results, section 2.1 for details. 


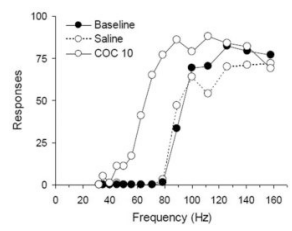

Figure 2.

Representative ICSS rate-frequency curves from one mouse before (black circles) and after injection of saline (white circles, dashed) or cocaine (COC10; white circles, solid). In this example, baseline pre-injection BSR threshold $\left(\theta_{0}\right)$ was $83.2 \mathrm{~Hz}$, was not significantly changed $(78.4 \mathrm{~Hz})$ after saline injection; and was lowered by cocaine $10 \mathrm{mg} / \mathrm{kg}$ i.p. to 51.5 $\mathrm{Hz}$, or $62 \%$ of baseline $\theta_{0}$. See Experimental Procedure, section 4.2 for details. 


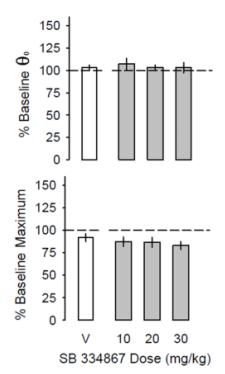

Figure 3.

Effect of the orexin-A receptor antagonist SB 334867 (gray bars) and vehicle (20\% v/v $\mathrm{DMSO}+25 \% \mathrm{w} / \mathrm{v}$ cyclodextrin in sterile normal saline; white bars) on BSR threshold $\left(\theta_{0}\right)$ and maximum operant response rate. No significant effect of time after injection was observed. Data are averaged over 60 minutes and expressed as mean effects \pm S.E.M. at each dose $(n=13)$. 

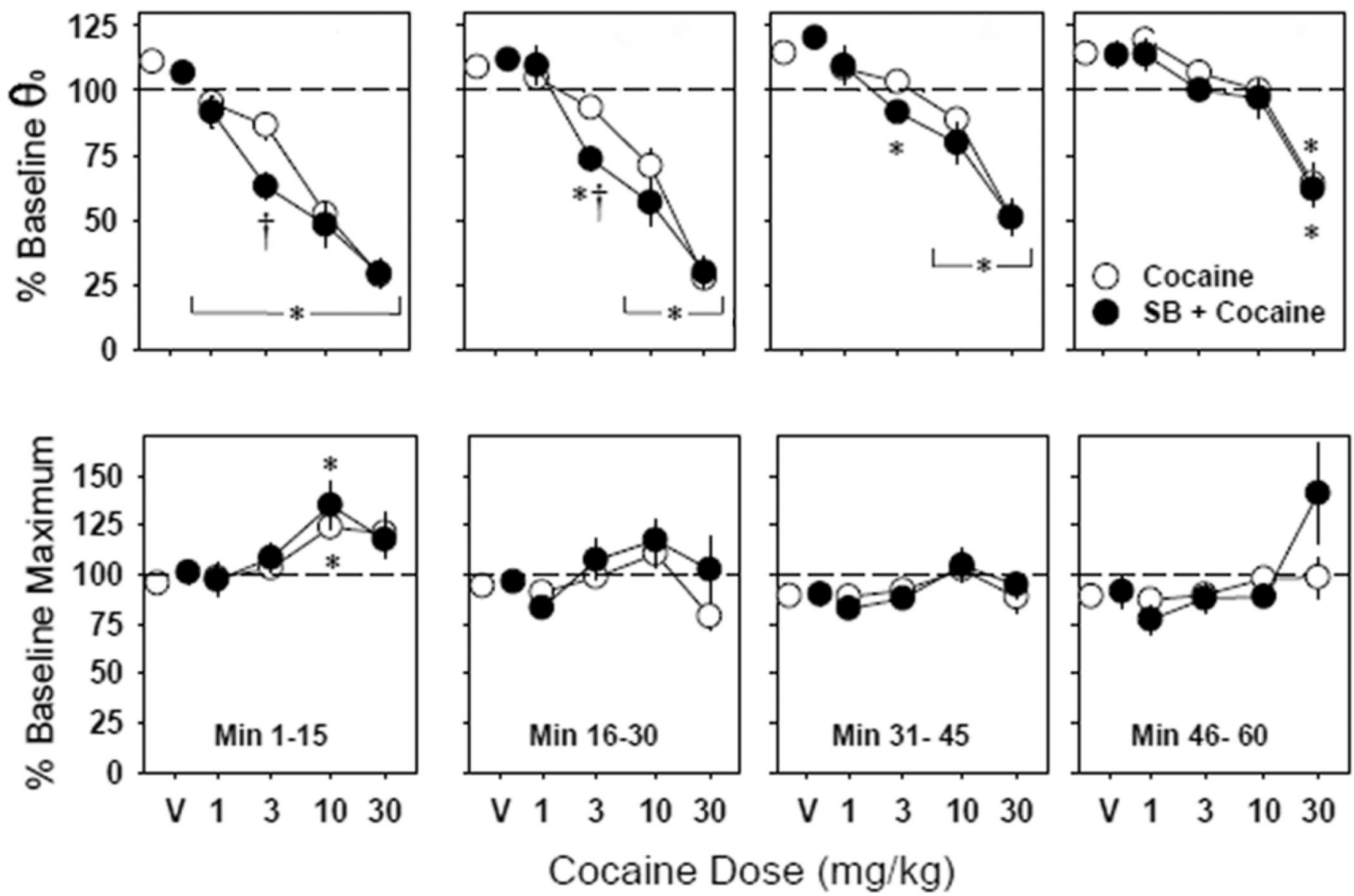

Cocaine Dose $(\mathrm{mg} / \mathrm{kg})$

Figure 4.

Effect of cocaine on BSR threshold $\left(\theta_{0}\right)$ and maximum operant response rate with (black circles) or without (white circles) prior administration of the orexin-A receptor antagonist SB $334867(30 \mathrm{mg} / \mathrm{kg})$. The first data point at each 15-minute epoch (V) represents the effects of vehicle ("Cocaine") or SB 334867 alone ("SB + Cocaine"). Data at each dose and time point are expressed as mean effects \pm S.E.M. $(n=12) . *=P<0.05$ vs. vehicle; $\dagger=P$ $<0.05$ vs. cocaine alone. 


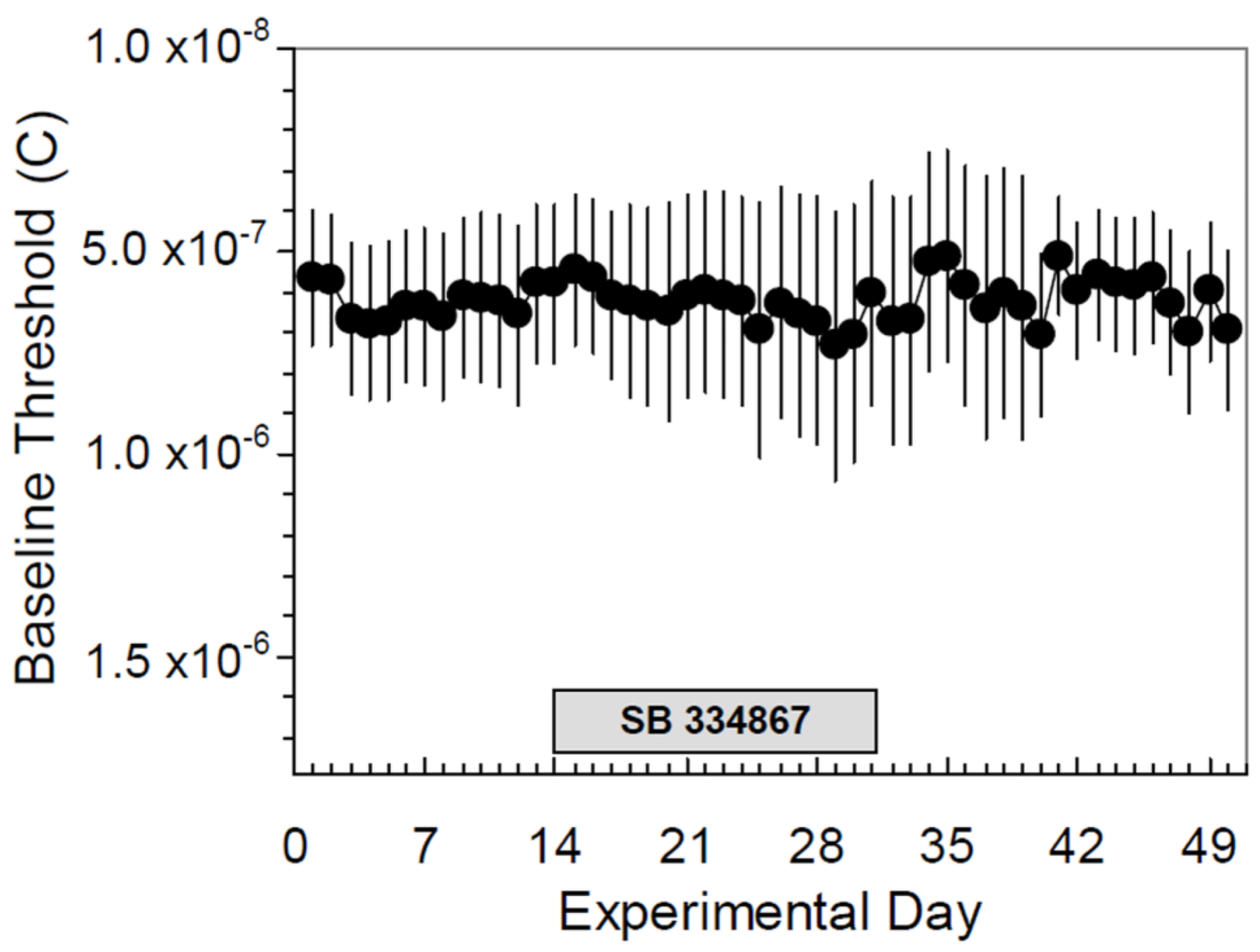

Figure 5.

Effect of the orexin-A receptor antagonist SB 334867 on preinjection baseline BSR threshold expressed as charge delivery (in Coulombs, C) at $\theta_{0}$ across the course of the experiment. No significant change in baseline $\theta_{0}$ was seen during or after every other day testing with $\mathrm{SB} \pm$ cocaine (days 14-31). Data are expressed as mean baseline $\theta_{0} \pm$ S.E.M. on each day $(n=12)$. 


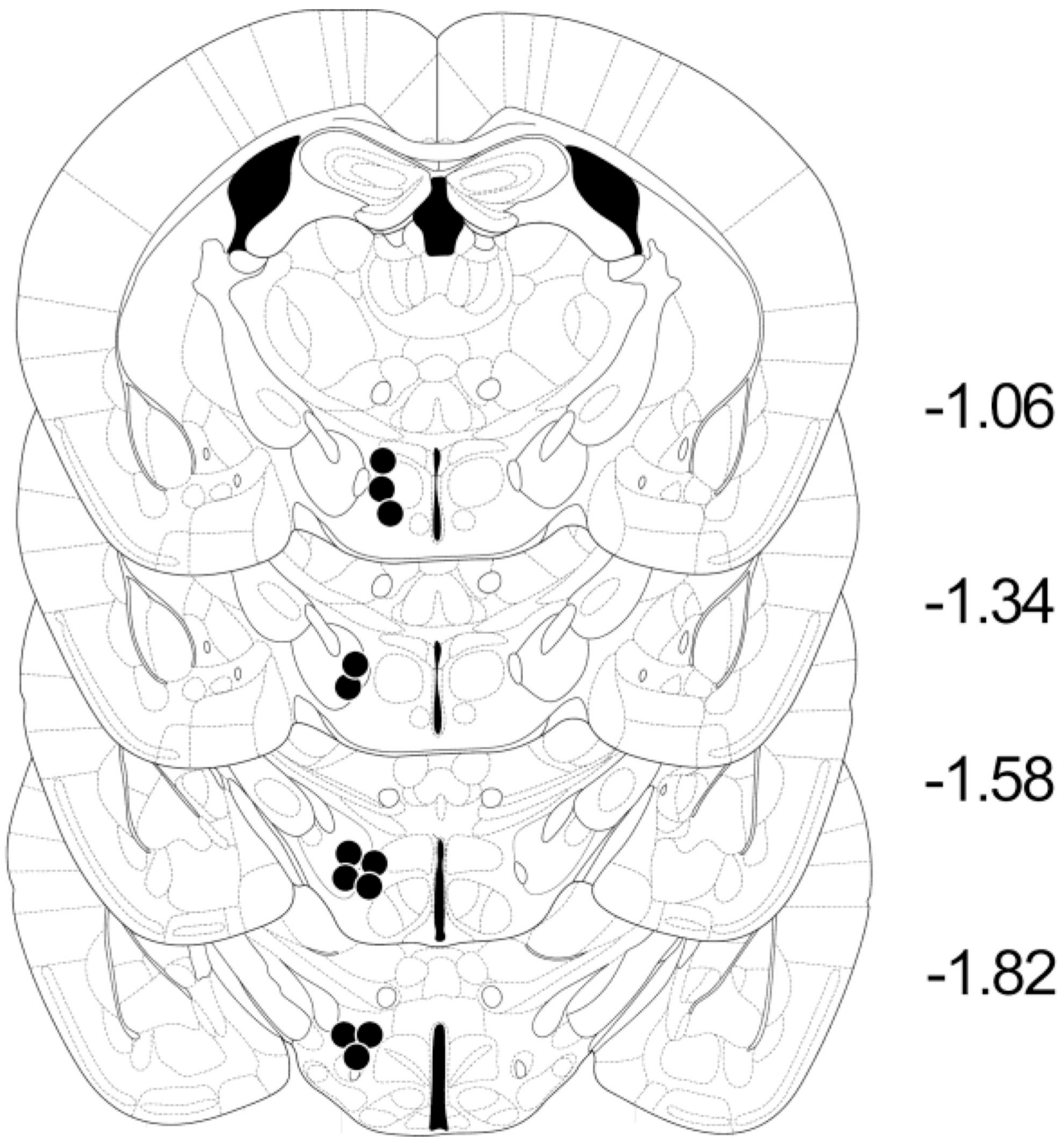

Figure 6.

ICSS electrode placements in the medial forebrain bundle at the level of the lateral hypothalamus $(n=13)$. Electrode tip locations are plotted on templates from the standard mouse stereotaxic atlas (Paxinos and Franklin 1996) by manual inspection of Nissl-stained sections. All electrodes were implanted on the right $(\mathrm{m} / \mathrm{l}=-0.8 \mathrm{~mm})$. See Experimental Procedure, section 4.3 for details. 
Riday et al.

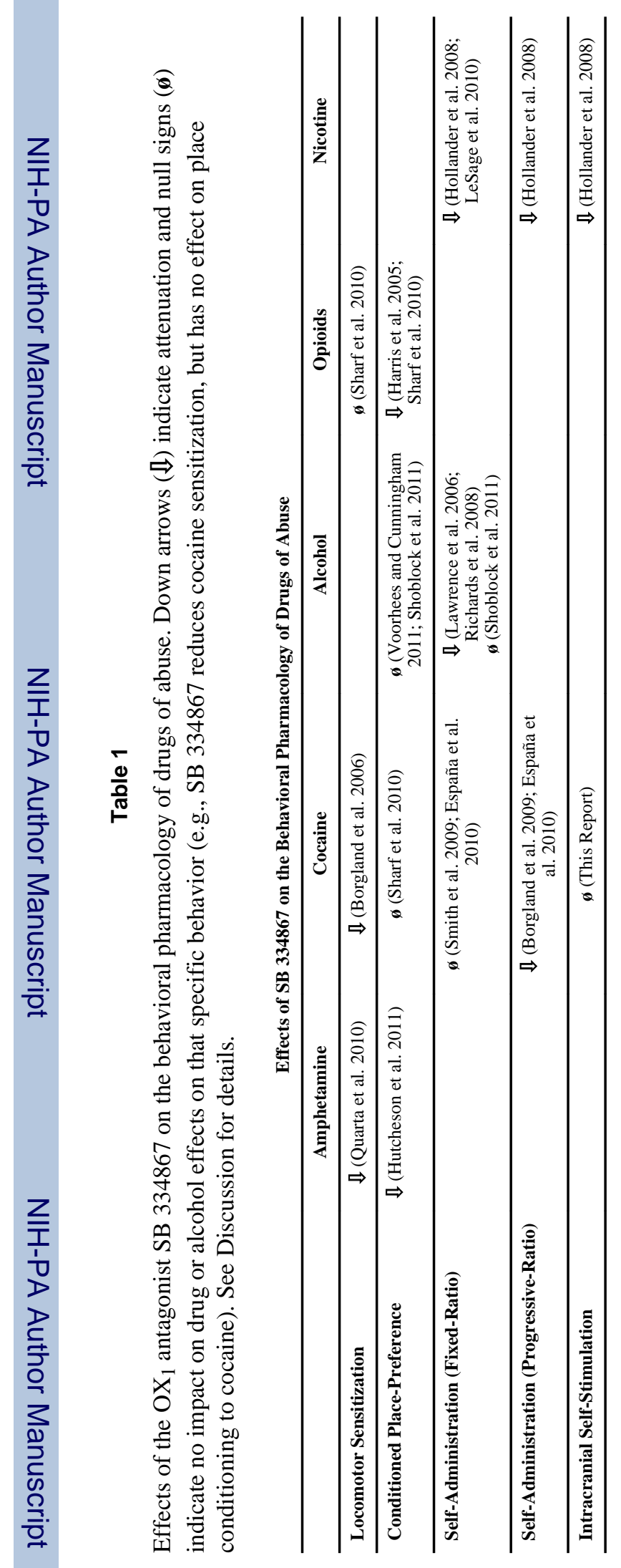

